\title{
Interferon- $\gamma$ down-regulates expression of tumor necrosis factor- $\alpha$ converting enzyme/a disintegrin and metalloproteinase 17 in activated hepatic stellate cells of rats
}

\author{
TOMOHIRO FUJITA $^{1,2}$, CHIHAYA MAESAWA ${ }^{1}$, KANTA OIKAWA ${ }^{1}$, \\ HIROYUKI NITTA $^{2}$, GO WAKABAYASHI ${ }^{2}$ and TOMOYUKI MASUDA ${ }^{1}$ \\ Departments of ${ }^{1}$ Pathology and ${ }^{2}$ Surgery I, Iwate Medical University School of Medicine, Morioka 020-8505, Japan
}

Received November 25, 2005; Accepted January 3, 2006

\begin{abstract}
Interferon- $\gamma(\mathrm{IFN}-\gamma)$ is a potent cytokine that exerts antiproliferative and antifibrogenic effects on hepatic stellate cells (HSCs). Although therapeutic application of IFN- $\gamma$ for chronic liver diseases is anticipated, the responses of activated HSCs to IFN- $\gamma$ have not been fully elucidated. To seek unknown molecules and pathways that might be responsive to IFN- $\gamma$ treatment in activated HSCs, we examined global protein expression profiles using two-dimensional gel electrophoresis combined with peptide mass fingerprint. We identified 76 increased and 59 decreased spots ( $>3$-fold increase or decrease, total 135 spots). Database analysis suggested that the following four pathways were involved in alteration of HSCs toward a quiescent phenotype in response to IFN- $\gamma$ : i) down-regulation of the TGF- $\beta$ and PDGF signaling pathways; ii) reorganization of intermediate filaments; iii) up-regulation of fatty acid metabolism; iv) decreased expression of TNF- $\alpha$ converting enzyme (TACE)/a disintegrin and metalloproteinase 17 (ADAM17), which is responsible for shedding of the proinflammatory cytokine TNF- $\alpha$. We confirmed down-regulation of both ADAM17 expression and soluble TNF- $\alpha$ secretion by Western blotting and real-time PCR. TNF- $\alpha$ mRNA/protein expression was not altered by IFN- $\gamma$ treatment. Our data suggest that IFN- $\gamma$ stimulation suppresses the activated phenotype of HSCs in vitro through multiple pathways. Of these pathways, down-regulation of ADAM17 expression may play a role in blocking the auto-activation mechanism of cultured HSCs through activation of the TNF- $\alpha$ signaling and shedding pathways.
\end{abstract}

Correspondence to: Dr Chihaya Maesawa, Department of Pathology, Iwate Medical University School of Medicine, 19-1 Uchimaru, Morioka 020-8505, Japan

E-mail: chiahaya@iwate-med.ac.jp

Key words: hepatic stellate cells, interferon- $\gamma$, tumor necrosis factor- $\alpha$, ADAM17, proteome

\section{Introduction}

Liver fibrosis is the common sequel of chronic liver injury regardless of its etiology (viral infection, metabolic disease or toxins). Many studies have suggested that hepatic stellate cells (HSCs) play a pivotal role in the initiation and/or progression of liver fibrosis (1-12). In normal liver, HSCs are the site of storage and metabolism of vitamin A $(6,7)$. Following chronic liver injury, HSCs undergo a process of activation, developing a myofibroblast-like appearance (1-12). Activated HSCs appear to lose their lipid droplets, increase their rough endoplasmic reticulum, express $\alpha$-smooth muscle actin ( $\alpha$-SMA), and increase their synthesis of extracellular matrix components and fibrosis-implementing factors, such as transforming growth factor- $\beta 1$ (TGF- $\beta 1)$ and platelet-derived growth factor receptor- $\beta$ (PDGFR- $\beta$ ) (1-12). Therefore, it is not surprising that activated HSCs are considered a major cellular target for the treatment of liver fibrosis.

Interferon- $\gamma(\mathrm{IFN}-\gamma)$ is a potent cytokine that exerts immunomodulatory and antiproliferative effects on certain mesenchymal cells. It has also been shown to have antifibrogenic effects on cultured fibroblasts (13-16), chondrocytes (17), cultured fetal bone (18) and vascular myofibroblasts (19). In vivo experiments have shown that locally or systemically administered recombinant murine IFN- $\gamma$ reduces the collagen content of skin wounds in mice (20). IFN- $\gamma$ also exerts antiproliferative and antifibrogenic effects on cultured HSCs (21). Moreover, IFN- $\gamma$-deficient mice exhibit an increased susceptibility to hepatic fibrosis after injury (22). Although therapeutic applications of IFN- $\gamma$ for chronic liver diseases are anticipated, the responses of activated HSCs to IFN- $\gamma$ have not been fully elucidated.

To seek unknown molecules that might be responsive to IFN- $\gamma$ treatment in activated HSCs, we examined global protein expression profiles using two-dimensional gel electrophoresis (2-DE) combined with peptide mass fingerprint (PMF)/postsource decay (PSD).

\section{Materials and methods}

Isolation of HSCs and culture conditions. HSCs were isolated and enriched using a modification of the method of Senoo (23). All rats were treated according to the Japanese National 
Guidelines for the Care of Animals. HSCs were isolated from male Wistar rats, weighing 250-300 g, by using collagenase digestion followed by density gradient centrifugation. After isolation, the cells were cultured in Dulbecco's modified Eagle's medium (DMEM; Invitrogen, Carlsbad, CA, USA) supplemented with $10 \%$ fetal bovine serum (FBS, Invitrogen). HSCs were incubated at $37^{\circ} \mathrm{C}$ in a humidified atmosphere with $5 \% \mathrm{CO}_{2}$, and the medium was changed twice a week. When the cells became confluent, they were trypsinized and replated on plastic culture dishes at a density of $1 \times 10^{6}$ cells $/ \mathrm{cm}^{2}$. Experiments were performed using cells after 3 passages from the primary culture for in vitro activation of HSCs.

IFN- $\gamma$ treatment. Treatment with recombinant rat interferon- $\gamma$ (IFN- $\gamma$; BioSource International Camarillo, CA, USA) was performed according to standard procedures to investigate the possible antifibrogenic effect of the compound, as described previously (24). Briefly, HSCs were plated and grown for 7 days until subconfluency. Subsequently, they were washed 5 times with serum-free DMEM. IFN- $\gamma$ was added to a final concentration of $1 \times 10^{3} \mathrm{U} / \mathrm{ml}$ in DMEM supplemented with $0.3 \%$ FBS (24). After treatment with IFN- $\gamma$ for 6,12 and $48 \mathrm{~h}$, mRNA and/or protein were extracted.

Preparation of cellular protein. The HSCs were harvested and washed 3 times with ice-cold Dulbecco's phosphatebuffered saline (PBS, Invitrogen). They were then dissolved in lysis buffer consisting of $7 \mathrm{M}$ urea, $2 \mathrm{M}$ thiourea, $4 \%$ (wt/vol) 3-3-cholamidopropyldimethylammonio-1-propanesulfonate, $1 \%$ dithiothreitol (DTT), and $0.5 \%$ (vol/vol) IPG buffer ( $\mathrm{pH}$ 4.0-7.0 and/or pH 3.0-10; Amersham Biosciences, Piscataway, NJ, USA). All samples were incubated for $1 \mathrm{~h}$ at room temperature, and then centrifuged for $1 \mathrm{~h}$ at 40,000 g to remove DNA. The protein concentration of each sample was measured using a Bio-Rad DC Protein Assay Kit (Bio-Rad Laboratories, Hercules, CA, USA), a microplate reader (Vmax, Molecular Devices, Sunnyvale, CA, USA) and SOFTmax PRO software (Molecular Devices).

Two-dimensional electrophoresis (2-DE). Using $300 \mu \mathrm{g}$ of cellular protein extracted from HSCs, isoelectric focusing (IEF) was carried out with Immobiline DryStrips (linear $\mathrm{pH}$ gradient 4.0-7.0, $18 \mathrm{~cm}$, non-linear $\mathrm{pH}$ gradient of 3-10, $24 \mathrm{~cm}$; Amersham Biosciences). The gels were rehydrated for 12-15 h by placing the strips gel side down in an Immobiline DryStrip Reswelling Tray (Amersham Biosciences), with rehydration solution covered by DryStrip Cover Fluid (Amersham Biosciences). IEF was carried out using an Ettan ${ }^{\mathrm{TM}}$ IPGphor $^{\mathrm{TM}}$ (Amersham Biosciences) at $20^{\circ} \mathrm{C}$. The first phase was set at $500 \mathrm{~V}$ for $1 \mathrm{~min}$, and the second phase at $4,000 \mathrm{~V}$ for $1.5 \mathrm{~h}$. Both phases were a linear gradient spanning for each time. The final phase was set at 8,000 V for 3-10 h. Prior to seconddimensional electrophoresis, the IPG gel strips were incubated at room temperature for $15 \mathrm{~min}$ in an equilibration solution (50 mM Tris- $\mathrm{HCl} / \mathrm{pH} 8.8,6 \mathrm{M}$ urea, 2\% SDS, 30\% glycerol, trace bromophenol blue and $1 \%$ DTT). This was followed by incubation for $15 \mathrm{~min}$ in the equilibration solution containing $2.5 \%$ iodoacetamide. The gels were subsequently subject to a second-dimensional run using an Ettan ${ }^{\mathrm{TM}}$ DALT Six Large Electrophoresis Unit (Amersham Biosciences) at $4^{\circ} \mathrm{C}$ on Ettan
DALT Gel (12.5\%, 26x20 cm, Amersham Biosciences). The first phase was set at $2.5 \mathrm{~W} / \mathrm{gel}$ for $30 \mathrm{~min}$. The second phase was set at $100 \mathrm{~W}$ for $3.5-5 \mathrm{~h}$ until the bromophenol blue reached the bottom of the gel. The 2-DE gels were finally stained with a Silver Staining Kit, Protein (Amersham Biosciences).

Gel analysis. The silver-stained 2-DE gels were scanned on an Epson ES 2200 scanner (Seiko Epson Corp., Suwa, Japan) and the images were processed using Adobe Photoshop software (version 5.0, San Jose, CA, USA). Spot detection and matching were performed using the PDQuest version 7.2 software package (Bio-Rad). Protein spots were checked manually to eliminate artifacts due to gel distortion, abnormal silver staining or poorly detectable spots. Protein level of each spot with an increased or decreased 3-fold over the untreated controls after treatment with INF- $\gamma$ was considered to show a substantial change. We used a 'Total Quantity in Valid Spots' method as the normalization method.

In-gel digestion. Spots of interest were manually excised from 2-DE gels and transferred to a ZipPlate micro-SPE plate (Millipore, Bedford, MA, USA). The procedure employed was essentially as described previously $(25,26)$ with slight modifications.

Matrix-assisted laser desorption/ionization time of flight mass spectrometry analysis. Mass information on the peptides was obtained using a MALDI-TOF (matrix-assisted laser desorption/ionization time of flight) mass spectrometer (Voyager $^{\mathrm{TM}}$ DE-STR, Applied Biosystems, Foster City, CA, USA) according to a previously published protocol. The peptide mixture $(1 \mu \mathrm{l})$ was crystallized with an equivalent volume of freshly prepared $\alpha$-cyano-4-hydroxycinnamic acid matrix solution $(10 \mathrm{mg} / \mathrm{ml}$; Sigma Chemical Co., St. Louis, MO, USA) in $50 \%$ acetonitrile (Sigma) $/ 0.1 \%$ trifluoroacetic acid (Kanto Chemical, Tokyo, Japan) onto the MALDI target plate. TOF spectra were acquired over the $\mathrm{m} / \mathrm{z}$ range of 700-3,000 Da in the delayed extraction and reflector mode. External calibration was performed using Angiotensin I $\left(\mathrm{M}^{+} \mathrm{H}^{+}, 1,296.70 \mathrm{Da}\right)$, ACTH (clip 1-17 $\left.\mathrm{M}^{+} \mathrm{H}^{+}, 2,093.08 \mathrm{Da}\right)$, ACTH (clip 18-39 $\mathrm{M}^{+} \mathrm{H}^{+}, 2,465.20 \mathrm{Da}$ ) and ACTH (clip 7-38 $\left.\mathrm{M}^{+} \mathrm{H}^{+}, 3,657.93 \mathrm{Da}\right)$ in the same series as the samples to be measured. Internal calibration was also performed using autodigestion peaks of trypsin $\left(\mathrm{M}^{+} \mathrm{H}^{+}, 842.51\right.$ and 2,211.10 Da). TOF spectra were acquired over the $\mathrm{m} / \mathrm{z}$ range of $700-3,000 \mathrm{Da}$ in the delayed extraction and reflector mode.

Initially, the samples were subjected to peptide mass fingerprint (PMF) analysis. The resulting peptide masses were then searched against the SWISS-PROT and NCBI non-redundant databases using the MS-fit software package (http://prospector. ucsf.edu/ucsfhtm14.0/msfit.htm; Protein Prospector, UCSF, San Francisco, CA, USA). The MS-fit search was performed with the following parameters: all molecular weight ranges, all $\mathrm{pH}$ ranges, oxidation of methionine, acetylation of the $\mathrm{N}$-terminus, carboxyamidomethylation of cysteine, and phosphorylation of serine, threonine and tyrosine. Positive identification of a protein was assigned only if at least five peptide masses matched a particular hit in the database within a mass tolerance of $50 \mathrm{ppm}$ or lower, matched peptide 

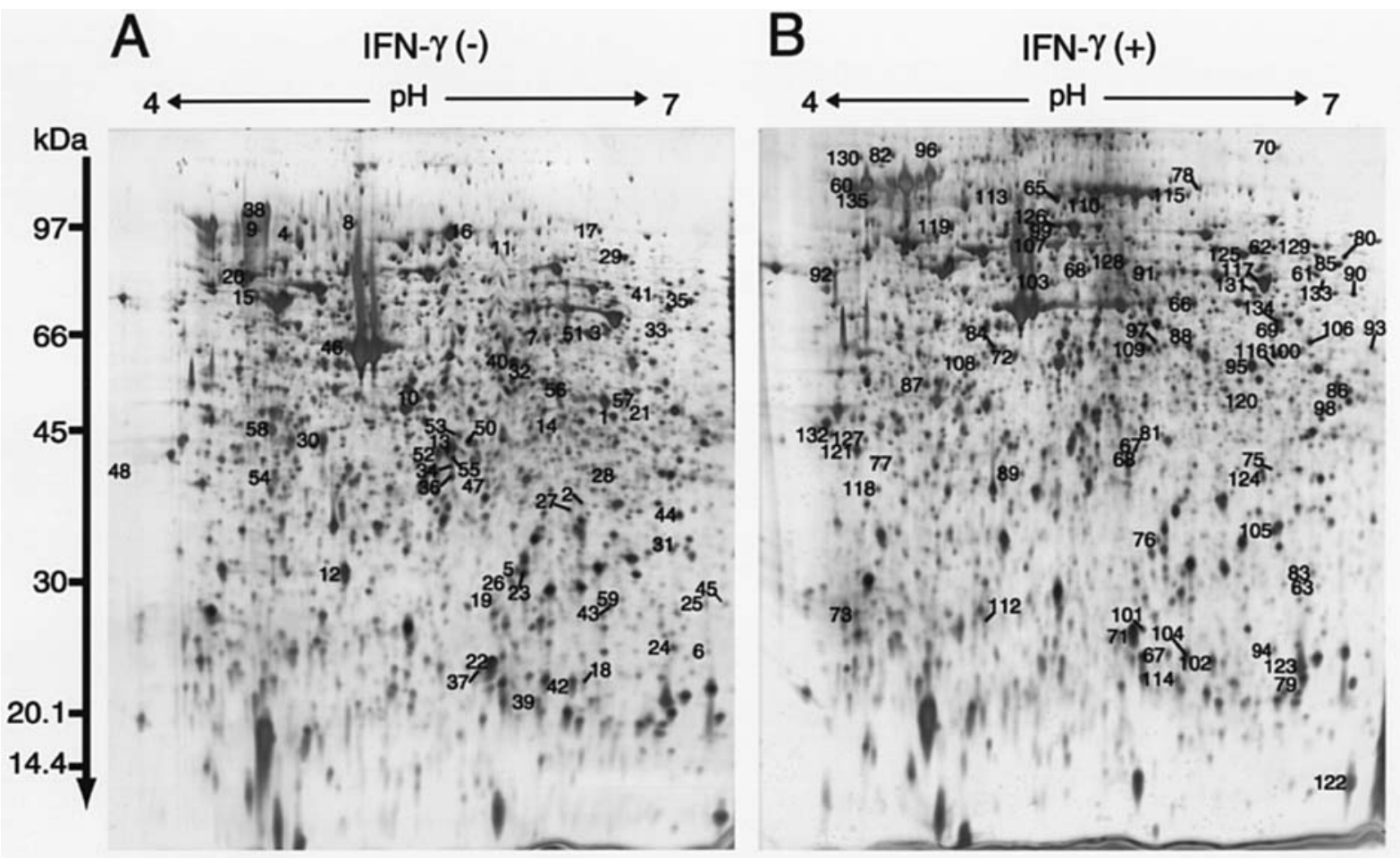

Figure 1. Two-DE pattern of proteins extracted from HSCs without (A) and with (B) IFN- $\gamma$ treatment for $48 \mathrm{~h}$. The proteins (300 $\mu \mathrm{g})$ were separated by $2-\mathrm{DE}$ (IPG gel strip, $18 \mathrm{~cm}, \mathrm{pH}$ 4.0-7.0) and the proteins in the second-dimension gel were silver-stained. Representative numbers are identical to those in Tables I and II. Fifty-nine decreased and 76 increased spots were indicated in gels A and B, respectively.

masses were evenly distributed throughout its amino acid sequence, and the identified protein's molecular weight and $\mathrm{pH}$ approximated experimental values, with some exceptions. Protein spots that could not be matched convincingly with any database hit, or spots that contained unidentified peaks, were further subjected to post-source decay (PSD) analysis. The resulting peptide masses were then searched against the SWISS-PROT and NCBI non-redundant databases using the MS-Tag software package (http://prospector.ucsf.edu/ ucsfhtm14.0/mstagfd.htm; Protein Prospector). Positive protein identification was confirmed by comparing its theoretical tryptic peptide digests with MALDI spectra, obtaining additional sequence information from another peptide, and using the Mascot Program (http://www.matrixscience.com/) to reconfirm the hit.

RNA extraction and real-time quantitative PCR. Total RNA was extracted with an RNeasy Mini Kit (Qiagen Sciences, Valencia, CA, USA) according to the manufacturer's protocol, and cDNA was synthesized with a Thermoscript RT-PCR Kit (Invitrogen) and oligo-dT primer. We performed the real-time quantitative PCR assay with an ABI PRISM 7700 Sequence Detector (Applied Biosystems). Primers were designed with Primer Express software (Applied Biosystems). The reaction mixture contained $50 \mathrm{ng}$ of cDNA, $100 \mathrm{nmol} / \mathrm{l}$ each primer, and $25 \mu 1$ of SYBR Green PCR Master Mix (Applied Biosystems) in a final volume of $50 \mu 1$. The cDNA was subjected to 50 cycles of a two-step PCR consisting of $15 \mathrm{sec}$ denaturation at $95^{\circ} \mathrm{C}$ and $1 \mathrm{~min}$ combined annealing/extension at $60^{\circ} \mathrm{C}$. Each sample was run in triplicate in separate tubes. For normalization of each target in the samples, the glyceraldehyde-3-phosphate dehydrogenase (GAPDH) gene was used as an internal control (Applied Biosystems). Primer sequences for tumor necrosis factor (TNF)- $\alpha$ converting enzyme (TACE)/a disintegrin and metalloproteinase 17 (ADAM17) were ADAM17-F-GTG CTG ACA CCG ACA ACT CGT and ADAM17-R-CAG CTG GTC AAT GAA ATC CCA, and those of tumor necrosis factor (TNF)- $\alpha$ were TNF- $\alpha-F-C A G$ CCG GTT TGC CAT TTC AT and TNF- $\alpha-R-G G T$ GTC CTT AGG GCA AGG GC. All data were calculated by the comparative $\mathrm{Ct}$ method (27) to detect fold changes in mRNA expression.

Western blot analysis. We examined several proteins by Western blot analysis. The primary antibodies used were monoclonal $\alpha$-SMA $(1: 1,000$; Sigma), polyclonal antiPDGFR-B (Clone 958, 1:1,000; Santa Cruz, CA, USA), polyclonal anti-TGF-ß1 (sc-146, 1:500; Santa Cruz), polyclonal anti-ADAM-17 (1:1,000; Sigma), monoclonal anti-tumor necrosis factor- $\alpha(1: 1,000$; Sigma), and monoclonal anti- $\beta$-actin $(1: 1,000 ;$ Sigma). The secondary antibody, anti-mouse IgG or anti-rabbit IgG (Amersham Biosciences), was diluted 1:10,000 in blocking buffer. Immunoreactive bands were visualized with an ECL Plus System (Amersham Biosciences).

Cytokine assay. To evaluate the increase of TNF- $\alpha$ secretion in the supernatant of HSC cultures, we employed a LabMAP (Multi-Analyte Profiling) system, which is based on antibodycoupled microspheres and flow cytometer assay, and has been used for quantifying multiple cytokines in several biological fluids including human serum. The method is feasible and cost-effective for cytokine profiling. We used a Bio-Plex ${ }^{\mathrm{TM}}$ RAT Cytokine 8-Plex Panel (Bio-Rad Laboratories, Inc.) and a Bio-Plex Suspension Array System (Bio-Rad). The limits 
Table I. Proteins showing down-regulation in activated hepatic stellate cells after treatment with IFN- $\gamma$ for $48 \mathrm{~h}$, detected by two-dimensional gel electrophoresis combined with peptide mass fingerprint/post-source decay.

\begin{tabular}{ccccccc}
\hline No. & $\begin{array}{c}\text { Swiss-Plot } \\
\text { Accession no. }\end{array}$ & Pep & M & $\begin{array}{c}\text { Fold } \\
\text { change }\end{array}$ & $\begin{array}{c}\text { Gene } \\
\text { symbol }\end{array}$ & Protein name \\
\hline
\end{tabular}

\begin{tabular}{|c|c|c|c|c|c|c|}
\hline \multicolumn{7}{|c|}{ Binding } \\
\hline 1 & P25977 & 6 & 71 & -11.3 & Acta2 & Nucleolar transcription factor 1 \\
\hline 2 & Q99PK0 & 10 & 99 & -7.7 & $\mathrm{Xab} 2$ & XPA-binding protein 2 \\
\hline 3 & Q9Z1K9 & 5 & 93 & -7.4 & Adam 17 & ADAM 17 \\
\hline 4 & Q9QY02 & 6 & 85 & -4.8 & Yt521 & Putative splicing factor YT521 \\
\hline 5 & Q9R011 & 5 & 68 & -4.6 & Plk3 & Serine/threonine-protein kinase PLK3 \\
\hline 6 & Q63202 & 5 & 82 & -3.9 & Adam2 & ADAM 2 \\
\hline 7 & P97834 & 8 & 53 & -3.9 & Gps1 & COP9 signalosome complex subunit 1 \\
\hline 8 & Q9ESM2 & 5 & 38 & -3.9 & Hapln2 & Hyaluronan and proteoglycan link protein 2 \\
\hline 9 & P55063 & 10 & 70 & -3.6 & Hspa11 & Heat shock $70 \mathrm{kDa}$ protein $1 \mathrm{~L}$ \\
\hline 10 & P04276 & 8 & 53 & -3.6 & Gc & Vitamin D-binding protein \\
\hline 11 & Q99P74 & 5 & 24 & -3.5 & Rab27b & Ras-related protein Rab-27B \\
\hline 12 & P06761 & 6 & 72 & -3.2 & Hspa5 & 78-kDa glucose-regulated protein \\
\hline 13 & P97779 & 13 & 57 & -3.1 & $\mathrm{Hmmr}$ & Hyaluronan mediated motility receptor \\
\hline 14 & P13596 & 7 & 94 & -3.1 & Ncam 1 & Neural cell adhesion molecule $1140 \mathrm{kDa}$ isoform \\
\hline 15 & Q64725 & 5 & 71 & -3.1 & Syk & Tyrosine-protein kinase SYK \\
\hline \multicolumn{7}{|c|}{ Catalytic activity } \\
\hline 16 & P19637 & 10 & 62 & -13.2 & Plat & Tissue-type plasminogen activator \\
\hline 17 & Q60587 & 6 & 51 & -10.3 & Hadhb & Trifunctional enzyme $\beta$-subunit, mitochondrial \\
\hline 18 & Q64595 & 7 & 87 & -7.3 & Prkg2 & cGMP-dependent protein kinase 2 \\
\hline 19 & P19468 & 7 & 72 & -6.8 & Gclc & Glutamate-cysteine ligase catalytic subunit \\
\hline 20 & Q9EQS0 & 5 & 37 & -5.9 & Taldo1 & Transaldolase \\
\hline 21 & Q64637 & 9 & 60 & -5.8 & Ugt1 & UDP-glucuronosyltransferase 1-3 precursor, microsomal \\
\hline 22 & P06536 & 5 & 87 & -5.7 & $\mathrm{Nr} 3 \mathrm{c} 1$ & Glucocorticoid receptor \\
\hline 23 & P13195 & 6 & 71 & -4.2 & Alas1 & 5-aminolevulinate synthase, non-specific, mitochondrial \\
\hline 24 & P14646 & 5 & 82 & -4.1 & Pde $4 b$ & cAMP-specific 3',5'-cyclic phosphodiesterase 4B \\
\hline 25 & P18589 & 6 & 75 & -3.9 & $\mathrm{Mx} 2$ & Interferon-induced GTP-binding protein $\mathrm{Mx} 2$ \\
\hline 26 & P35571 & 7 & 80 & -3.6 & Gpd2 & Glycerol-3-phosphate dehydrogenase, mitochondrial \\
\hline 27 & P20069 & 5 & 58 & -3.6 & Pmpca & $\begin{array}{l}\text { Mitochondrial processing peptidase } \alpha \text { subunit, } \\
\text { mitochondrial }\end{array}$ \\
\hline 28 & P09811 & 8 & 97 & -3.5 & Pygl & Glycogen phosphorylase, liver form \\
\hline 29 & Q8R4C0 & 8 & 73 & -3.4 & Capn5 & Calpain 5 \\
\hline 30 & Q63108 & 5 & 61 & -3.4 & Ces1 & Liver carboxylesterase 3 \\
\hline 31 & P35704 & 5 & 21 & -3.4 & $\operatorname{Prdx} 2$ & Peroxiredoxin 2 \\
\hline 32 & P28841 & 5 & 70 & -3.2 & Pcsk2 & Neuroendocrine convertase 2 \\
\hline 33 & O88496 & 5 & 87 & -3.2 & Ggcx & Vitamin K-dependent gamma-carboxylase \\
\hline 34 & P07153 & 5 & 68 & -3.1 & Rpn1 & $\begin{array}{l}\text { Dolichyl-diphosphooligosaccharide-protein glycosyl- } \\
\text { transferase } 67-\mathrm{kDa} \text { subunit }\end{array}$ \\
\hline 35 & P50282 & 6 & 78 & -3.1 & Mmp9 & Matrix metalloproteinase-9 \\
\hline 36 & Q9ES66 & 6 & 74 & -3.0 & Capn10 & Calpain 10 \\
\hline 37 & $\mathrm{O} 35776$ & 5 & 63 & -3.0 & Has2 & Hyaluronan synthase 2 \\
\hline 38 & Q64573 & 10 & 62 & -3.0 & Ces $1^{a}$ & Liver carboxylesterase 4 \\
\hline
\end{tabular}

Signal transducer activity 
Table I. Continued.

\begin{tabular}{|c|c|c|c|c|}
\hline No. & $\begin{array}{l}\text { Swiss-Plot Pep } \\
\text { Accession no. }\end{array}$ & $\begin{array}{cc}\text { M Fold } \\
\text { change }\end{array}$ & $\begin{array}{l}\text { Gene } \\
\text { symbol }\end{array}$ & Protein name \\
\hline
\end{tabular}

\begin{tabular}{|c|c|c|c|c|c|c|}
\hline \multicolumn{7}{|c|}{$\begin{array}{l}\text { Signal transducer } \\
\text { activity }\end{array}$} \\
\hline 40 & Q05030 & 6 & 56 & -5.5 & Pdgfrb & ß platelet-derived growth factor receptor \\
\hline 41 & P80204 & 5 & 56 & -4.1 & Tgfbr1 & TGF- $\beta$ receptor type I \\
\hline 42 & Q9R237 & 7 & 77 & -3.7 & Mapk8ip1 & c-jun-amino-terminal kinase interacting protein 1 \\
\hline 43 & O08876 & 8 & 51 & -3.6 & Klf10 & $\begin{array}{l}\text { Transforming growth factor- } \beta \text {-inducible early growth } \\
\text { response protein } 1\end{array}$ \\
\hline 44 & P42893 & 11 & 86 & -3.3 & Ece1 & Endothelin-converting enzyme 1 \\
\hline 45 & P17246 & 6 & 44 & -3.0 & Tgfb1 & Transforming growth factor- $\beta 1$ \\
\hline \multicolumn{7}{|c|}{$\begin{array}{l}\text { Structural } \\
\text { molecule a }\end{array}$} \\
\hline 46 & Q05764 & 13 & 80 & -9.9 & Add2 & $\beta$ adducin \\
\hline 47 & P31000 & 5 & 53 & -7.1 & Vim & Vimentin \\
\hline 48 & P04691 & 8 & 49 & -4.2 & Tubb & Tubulin $\beta$ chain \\
\hline 49 & P62738 & 14 & 42 & -3.3 & Acta2 & Actin, aortic smooth muscle \\
\hline 50 & P47819 & 7 & 49 & -3.0 & Gfap & Glial fibrillary acidic protein, astrocyte \\
\hline \multicolumn{7}{|c|}{$\begin{array}{l}\text { Transcription } \\
\text { regulator activity }\end{array}$} \\
\hline 51 & Q9JIL3 & 6 & 97 & -9.4 & Ilf3 & Interleukin enhancer-binding factor 3 \\
\hline \multicolumn{7}{|c|}{$\begin{array}{l}\text { Transporter } \\
\text { activity }\end{array}$} \\
\hline 52 & O88943 & 9 & 93 & -4.6 & Kcnq2 & Potassium voltage-gated channel subfamily KQT member 2 \\
\hline 53 & P10499 & 5 & 56 & -3.0 & Kena1 & Potassium voltage-gated channel subfamily A member 1 \\
\hline \multicolumn{7}{|l|}{ Others } \\
\hline 54 & P06399 & 5 & 86 & -10.3 & Fga & Fibrinogen $\alpha / \alpha$-E chain \\
\hline 55 & Q63083 & 6 & 53 & -9.3 & Nucb1 & Nucleobindin 1 \\
\hline 56 & Q99PV3 & 10 & 84 & -4.1 & Mkln1 & Muskelin \\
\hline 57 & P43884 & 5 & 55 & -4.1 & Plin & Perilipin \\
\hline 58 & Q02435 & 7 & 68 & -3.4 & Bfsp1 & Filensin \\
\hline 59 & P14480 & 6 & 54 & -3.0 & $\mathrm{Fgb}$ & Fibrinogen $ß$ chain \\
\hline
\end{tabular}

No., number (numbers are identical to those of Fig. 1); Pep, peptide; M, molecular mass; ainterim symbol.

of target detection were $2-32,000 \mathrm{pg} / \mathrm{ml}$. The assays were performed according to the manufacturer's instructions. Triplicate examinations were performed on each sample.

\section{Results}

Two-DE followed by PMF/PSD analysis. 2-DE gel separation was carried out to find proteins that were influenced by IFN- $\gamma$. After spot detection, background subtraction and volume normalization, $722 \pm 17.8$ and $747 \pm 21.1$ spots were seen in gels with and without IFN- $\gamma$ treatment, respectively (Fig. 1). We identified 123 increased and 64 decreased spots. Using PMF/PSD analysis, we were finally able to determine 76 increased and 59 decreased spots (Tables I and II, Fig. 1; Nos. in Fig. 1 are identical to those in Tables I and II). Functions of these proteins were annotated according to the Rat Genome Database (RDG; http://rgd.mcw.edu/, October 2005), and overrepresented gene groups with molecular functions (Gene Ontology, GO; http://www.geneontology.org/) (Tables I and II, Fig. 2). The number of proteins did not essentially differ between up- and down-regulated proteins in each molecular function category (Fig. 2).

Differential protein expression associated with an activated phenotype of HSCs under the influence of IFN- $\gamma$. Table III summarizes our data for markers of the activated phenotype of HSCs, myofibroblast-like cells, and activated fibroblasts. 
Table II. Proteins showing up-regulation in activated hepatic stellate cells after treatment with IFN- $\gamma$ for 48 h, detected by twodimensional gel electrophoresis combined with peptide mass fingerprint/post-source decay.

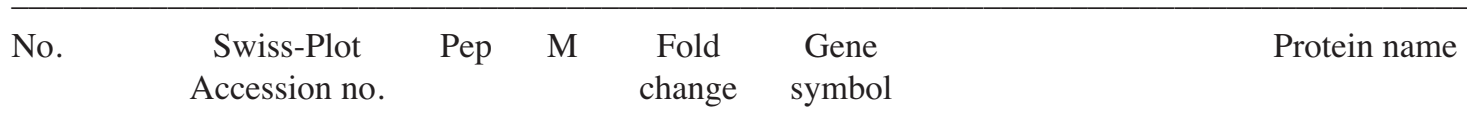

\begin{tabular}{|c|c|c|c|c|c|c|}
\hline \multicolumn{7}{|c|}{ Binding } \\
\hline 60 & Q9EPY0 & 7 & 62 & 91.7 & Card9 & Caspase recruitment domain protein 9 \\
\hline 61 & P51792 & 5 & 84 & 17.8 & Clen 3 & Chloride channel protein 3 \\
\hline 62 & Q62929 & 8 & 64 & 5.9 & $\mathrm{I} 11 \mathrm{r} 12$ & Interleukin-1 receptor-like 2 \\
\hline 63 & Q9Z2S9 & 6 & 47 & 5.6 & Flot2 & Flotillin-2 \\
\hline 64 & P48679 & 5 & 74 & 5.4 & Lmna & Lamin A \\
\hline 65 & O70418 & 6 & 68 & 5.2 & Znf179 & Zinc finger protein 179 \\
\hline 66 & P70531 & 7 & 81 & 4.7 & Eef2k & Elongation factor 2 kinase \\
\hline 67 & O88884 & 5 & 91 & 4.5 & Akap1 & A kinase anchor protein 1, mitochondrial \\
\hline 68 & P16446 & 8 & 31 & 4.3 & Pitpna & Phosphatidylinositol transfer protein $\alpha$ isoform \\
\hline 69 & P48037 & 5 & 75 & 3.6 & Anxa6 & Annexin A6 \\
\hline 70 & Q62698 & 8 & 54 & 3.6 & Dncli2 & Dynein light intermediate chain 2 , cytosolic \\
\hline 71 & O54835 & 6 & 48 & 3.6 & Smad9/8 & Mothers against decapentaplegic homolog 9 \\
\hline 72 & Q63598 & 5 & 70 & 3.5 & Pls3 & T-plastin \\
\hline 73 & Q63570 & 6 & 47 & 3.4 & Psmc4 & $26 \mathrm{~S}$ protease regulatory subunit $6 \mathrm{~B}$ \\
\hline 74 & O88797 & 6 & 82 & 3.3 & Dab2 & Disabled homolog 2 \\
\hline 75 & P35565 & 8 & 67 & 3.2 & Canx & Calnexin \\
\hline 76 & P35444 & 7 & 82 & 3.2 & Comp & Cartilage oligomeric matrix protein \\
\hline 77 & P14668 & 5 & 35 & 3.1 & Anxa5 & Annexin A5 \\
\hline 78 & Q924K2 & 6 & 73 & 3.1 & Faf1 & FAS-associated factor 1 \\
\hline 79 & Q62918 & 5 & 90 & 3.1 & Nell2 & Protein kinase C-binding protein NELL2 \\
\hline 80 & P20717 & 7 & 75 & 3.1 & Padi2 & Protein-arginine deiminase type II \\
\hline 81 & Q9JKT5 & 6 & 35 & 3.1 & Tas2r9 & Taste receptor type 2 member 9 \\
\hline 82 & P20417 & 5 & 49 & 17.8 & Ptpn1 & Tyrosine-protein phosphatase, non-receptor type 1 \\
\hline 83 & P47942 & 5 & 62 & 11.6 & Dpysl2 & Dihydropyrimidinase related protein-2 \\
\hline 84 & Q9QZ86 & 6 & 60 & 11.3 & Nop5 & Nucleolar protein NOP5 \\
\hline 85 & O54697 & 5 & 80 & 8.9 & Naaladl1 & $\mathrm{N}$-acetylated- $\alpha$-linked acidic dipeptidase like protein \\
\hline 86 & P20793 & 5 & 69 & 5.0 & Mak & Serine/threonine-protein kinase MAK \\
\hline 87 & P97679 & 6 & 84 & 4.5 & Mlh1 & DNA mismatch repair protein Mlh1 \\
\hline 88 & P51639 & 5 & 96 & 4.2 & Hmgcr & 3-hydroxy-3-methylglutaryl-coenzyme A reductase \\
\hline 89 & P32738 & 5 & 71 & 4.1 & Chat & Choline O-acetyltransferase \\
\hline 90 & P22791 & 5 & 56 & 4.0 & Hmgcs 2 & Hydroxymethylglutaryl-CoA synthase, mitochondrial \\
\hline 91 & P09812 & 5 & 97 & 3.9 & Pygm & Glycogen phosphorylase, muscle form \\
\hline 92 & P53042 & 5 & 56 & 3.9 & Ppp5c & Serine/threonine protein phosphatase 5 \\
\hline 93 & P53669 & 5 & 72 & 3.8 & Limk1 & LIM domain kinase 1 \\
\hline 94 & P41562 & 7 & 46 & 3.7 & Idh1 & Isocitrate dehydrogenase (NADP) cytoplasmic \\
\hline 95 & Q9QX05 & 8 & 96 & 3.6 & Tlr4 & Toll-like receptor 4 \\
\hline 96 & P14882 & 5 & 77 & 3.6 & Pcca & Propionyl-CoA carboxylase $\alpha$ chain, mitochondrial \\
\hline 97 & P51590 & 5 & 57 & 3.6 & Cyp2j3 & Cytochrome P450 2J3 \\
\hline 98 & P10760 & 5 & 47 & 3.6 & Ahcy & Adenosylhomocysteinase \\
\hline 99 & P29418 & 5 & 57 & 3.5 & Atp5e & ATP synthase epsilon chain, mitochondrial \\
\hline 100 & $\mathrm{P} 21575$ & 8 & 95 & 3.4 & Dnm1 & Dynamin-1 \\
\hline 101 & O54735 & 7 & 94 & 3.4 & Pde5a & cGMP-specific 3',5'-cyclic phosphodiesterase \\
\hline 102 & Q63151 & 11 & 80 & 3.4 & Acsl3 & Long-chain-fatty-acid-CoA ligase 3 \\
\hline 103 & P07896 & 5 & 78 & 3.4 & hadh & Peroxisomal bifunctional enzyme \\
\hline
\end{tabular}


Table II. Continued.

\begin{tabular}{lllllll}
\hline No. & $\begin{array}{c}\text { Swiss-Plot } \\
\text { Accession no. }\end{array}$ & Pep & M & $\begin{array}{c}\text { Fold } \\
\text { change }\end{array}$ & $\begin{array}{c}\text { Gene } \\
\text { symbol }\end{array}$ & Protein name \\
\hline $\begin{array}{c}\text { Catalytic activity } \\
104\end{array}$ & O35547 & 5 & 74 & 3.3 & Acs14 & Long-chain-fatty-acid-CoA ligase 4 \\
105 & P22443 & 5 & 58 & 3.3 & Cyp19a1 & Cytochrome P450 19A1 \\
106 & Q99JD2 & 7 & 48 & 3.3 & Tekt1 & Tektin-1 \\
107 & P06766 & 5 & 38 & 3.3 & Polb & DNA polymerase 3 \\
108 & P31325 & 8 & 46 & 3.2 & Phkg2 & Phosphorylase B kinase gamma catalytic chain, testis/liver \\
& & & & & & isoform \\
109 & Q08877 & 9 & 95 & 3.1 & Dnm3 & Dynamin 3 \\
110 & P97564 & 5 & 93 & 3.1 & Gpam & Glycerol-3-phosphate acyltransferase, mitochondrial \\
111 & O55096 & 5 & 83 & 3.1 & Dpp3 & Dipeptidyl-peptidase III \\
112 & P97524 & 8 & 70 & 3.1 & Slc27a2 & Very-long-chain acyl-CoA synthetase \\
113 & P15129 & 5 & 58 & 3.1 & Cyp4b1 & Cytochrome P450 4B1 \\
115 & P33124 & 8 & 78 & 3.0 & Acs16 & Long-chain-fatty-acid-CoA ligase 6 \\
116 & Q63802 & 6 & 71 & 3.0 & Wee1 & Wee1-like protein kinase \\
& P04642 & 6 & 36 & 3.0 & Ldha & L-lactate dehydrogenase A chain
\end{tabular}

Signal

transducer activity

117
118
119
120
121
122

$\begin{array}{lllll}\text { P31421 } & 7 & 95 & 4.4 & \text { Grm2 } \\ \text { P49805 } & 7 & 77 & 4.1 & \text { Rgs9 } \\ \text { P31422 } & 6 & 98 & 3.9 & \text { Grm3 } \\ \text { P37230 } & 5 & 52 & 3.4 & \text { Ppara } \\ \text { P97636 } & 6 & 22 & 3.3 & \text { Il18 } \\ \text { P17945 } & 6 & 82 & 3.1 & \text { Hgf }\end{array}$

Metabotropic glutamate receptor 2

Regulator of G-protein signaling 9

Metabotropic glutamate receptor 3

Peroxisome proliferator activated receptor $\alpha$

Interleukin-18

Structural

molecule activity

123

P48675

653

3.9

Des

Desmin

Transcription

regulator activity

124

P43301

542

4.0

Egr3

Early growth response protein 3

Enzyme

regulator activity

$\begin{array}{cllllll}125 & \text { Q9Z272 } & 5 & 85 & 3.9 & \text { Git1 } & \text { ARF GTPase-activating protein GIT1 } \\ 126 & \text { P05710 } & 5 & 68 & 3.7 & \text { Prlr } & \text { Prolactin receptor } \\ 127 & \text { P37727 } & 5 & 72 & 3.6 & \text { Chm } & \text { Rab proteins geranylgeranyltransferase component A 1 } \\ \text { Others } & & & & & & \\ 128 & \text { P48998 } & 7 & 67 & 5.5 & \text { Ivl } & \text { Involucrin } \\ 129 & \text { P12839 } & 8 & 95 & 3.6 & \text { Nef3 } & \text { Neurofilament triplet M protein } \\ 130 & \text { P97675 } & 5 & 99 & 3.4 & \text { Ennp3 } & \text { Ectonucleotide pyrophosphatase/phosphodiesterase 3 } \\ 131 & \text { Q9QZ81 } & 6 & 97 & 3.4 & \text { Eif2c2 } & \text { Eukaryotic translation initiation factor 2C 2 } \\ 132 & \text { Q64548 } & 5 & 83 & 3.4 & \text { Rtn1 } & \text { Reticulon 1 } \\ 133 & \text { O55197 } & 5 & 52 & 3.1 & \text { C3ar1 } & \text { C3a anaphylatoxin chemotactic receptor } \\ 134 & \text { Q62774 } & 7 & 97 & 3.1 & \text { Myo1a } & \text { Myosin Ia } \\ 135 & \text { P57790 } & 6 & 69 & 3.0 & \text { Keap1 } & \text { Kelch-like ECH-associated protein 1 }\end{array}$

No., number (numbers are identical to those of Fig. 1); Pep, peptide; M, molecular mass. 


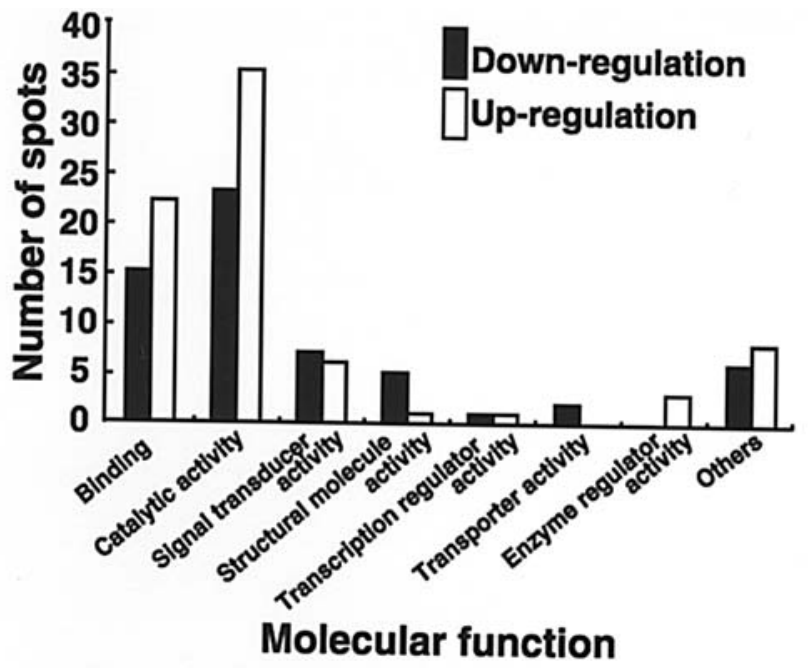

Figure 2. Histograms of proteins altered by IFN- $\gamma$ treatment. Protein annotation corresponds to molecular function (Gene Ontology, GO; http://www. geneontology.org/)

We found that IFN- $\gamma$ treatment resulted in down-regulation of structural molecules, $\alpha$-SMA (Acta2), vimentin (Vim), and glial fibrillary acidic protein (Gfap), which are conspicuous marker proteins that are up-regulated in activated HSCs, myofibroblast-like cells and/or activated fibroblasts (Table III). The expression of desmin (Des), which is also an activated marker for these cell types, was also up-regulated by IFN- $\gamma$. Both tubulin $B$ chain (Tubb) and beta adductin (Add2), whose relationship to HSC activation has not yet been fully described, were down-regulated by IFN- $\gamma$ treatment.

Among cytokines, growth factors and their receptors, three well-described fibrosis-implementing factors, $\beta$ platelet-derived growth factor receptor (Pdgfrb), transforming growth factor- $\beta 1$ (Tgfb1), and TGF- $\beta$ type I receptor (Tgfbr1), were downregulated upon treatment with IFN- $\gamma$ (Table III). Basic fibroblast growth factor receptor 1 (Fgfr1) was also down-regulated. It was noteworthy that hepatocyte growth factor (Hgf), which contributes to hepatocyte proliferation and prevention of liver fibrosis, was up-regulated. Two cytokine-related proteins, interleukin-18 (Il18) and interleukin-1 receptor-like 2 (Il1rl2), were also up-regulated (Table III).

Using Western blot analysis, we confirmed changes in the expression of several proteins. Marked down-regulation of $\alpha$-SMA and TGF- $\beta 1$ was observed with IFN- $\gamma$ treatment, whereas PDGFR- $\beta 1$ was slightly down-regulated. Quantitative results obtained by 2-DE and Western blotting were not always precisely matched.

Among extracellular matrix components, the expression of three proteins associated with hyaluronic acid synthesis was down-regulated upon treatment with IFN- $\gamma$ (Table III). Unfortunately, we were unable to examine exocrine proteins (e.g., collagen content) in the culture supernatant, because the action of IFN- $\gamma$ on HSCs requires a small amount of FBS $(0.3 \%)$, and this would have interfered with accurate 2-DE analysis of the supernatant contents.

Five proteases were down-regulated by IFN- $\gamma$ treatment. It is well known that suppression of plasminogen activator (Plat) and matrix metalloproteinase-9 (Mmp9) contributes to

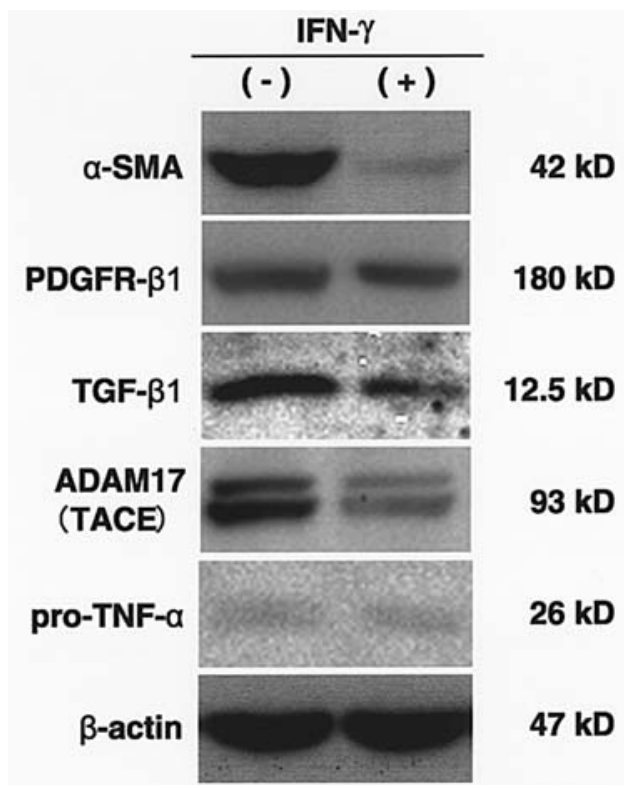

Figure 3. Western blot analysis of a structural molecule ( $\alpha$-SMA), fibrosisimplementing factors (PDGFR- $\beta 1$ and TGF- $\beta 1$ ), ADAM17, and pro-TNF- $\alpha$ $(26 \mathrm{kDa})$ after IFN- $\gamma$ treatment for $48 \mathrm{~h}$. Marked down-regulation of $\alpha$-SMA, TGF- 31 and ADAM17 was observed, and a slight decrease was seen in PDGFR- $\beta 1$. No change in pro-TNF- $\alpha$ expression was evident.

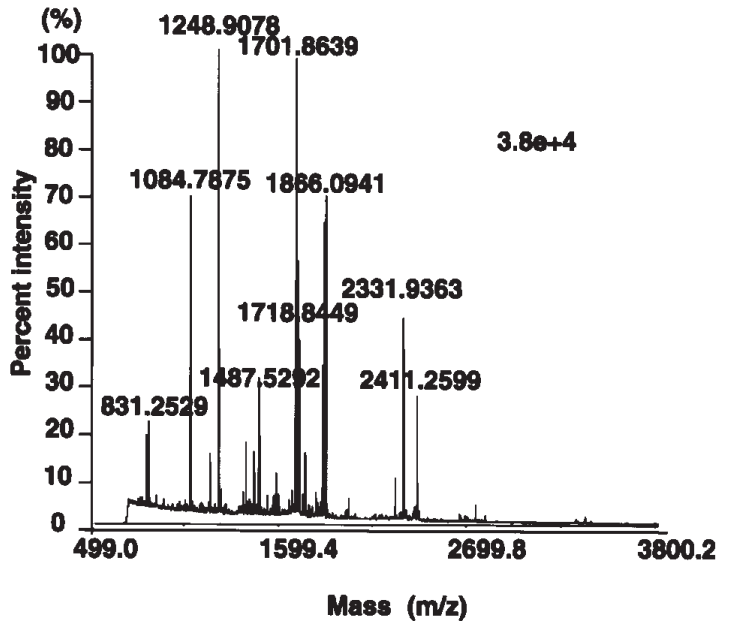

Figure 4. MALDI-TOF MS fingerprint pattern for a spot of interest (No. 3 in Fig. 1A) digested with trypsin. Fingerprint mass spectra were generated via MALDI-TOF MS analysis. The predicted peptide fragments corresponding to the observed $\mathrm{m} / \mathrm{z}$ values indicated ADAM17.

repression of fibrosis not only in skin wounds but also the liver. Interestingly, two members of the ADAM family were down-regulated. ADAM2 is associated with spermatogenesis. ADAM17 (no. 3 in Fig. 1A and Fig. 4) plays a pivotal role in the cleavage of membrane-associated cytokines (e.g., TNF- $\alpha$ ) and receptors (e.g., TNF receptor) and thereby regulates inflammatory and immune events, as well as embryo development. We examined the expression of ADAM17 and TNF- $\alpha$ under the influence of IFN- $\gamma$, and this is described in a later section below.

Four enzymes of long-chain fatty acid synthesis were upregulated with IFN- $\gamma$ treatment. Hepatocytes take up retinol 
Table III. Summary of genes of interest associated with phenotypes of activated HSCs.

\begin{tabular}{|c|c|c|c|c|c|c|c|c|c|c|}
\hline & \multicolumn{5}{|c|}{ Well described genes } & \multicolumn{5}{|c|}{ Not described genes } \\
\hline & \multirow[t]{2}{*}{ No. } & \multirow[t]{2}{*}{$\begin{array}{c}\text { Fold } \\
\text { change }\end{array}$} & \multirow[t]{2}{*}{$\begin{array}{c}\text { Gene } \\
\text { symbol }\end{array}$} & \multicolumn{2}{|c|}{$\begin{array}{l}\text { Status of mRNA/ } \\
\text { protein expression }\end{array}$} & \multirow[t]{2}{*}{ No. } & \multirow[t]{2}{*}{$\begin{array}{l}\text { Fold } \\
\text { change }\end{array}$} & \multirow[t]{2}{*}{$\begin{array}{c}\text { Gene } \\
\text { symbol }\end{array}$} & \multicolumn{2}{|c|}{$\begin{array}{l}\text { Status of mRNA/ } \\
\text { protein expression }\end{array}$} \\
\hline & & & & HSC & MFLC/AF & & & & $\mathrm{HSC}$ & MFLC/AF \\
\hline \multicolumn{11}{|l|}{ Down-regulation } \\
\hline \multirow[t]{2}{*}{ Extracellular matrix } & 37 & -3.0 & Has2 & $\mathrm{NE}$ & $\mathrm{I}$ & 8 & -3.9 & Hapln2 & $\mathrm{NE}$ & $\mathrm{NE}$ \\
\hline & & & & & & 13 & -3.1 & $\mathrm{Hmmr}$ & $\mathrm{NE}$ & NE \\
\hline \multirow{3}{*}{$\begin{array}{l}\text { Protease/protease } \\
\text { inhibitor }\end{array}$} & 16 & -13.2 & Plat & $\mathrm{I}$ & I & 3 & -7.4 & Adam17 & $\mathrm{NE}$ & I \\
\hline & 44 & -3.3 & Ece1 & $\mathrm{I}$ & I & 6 & -3.9 & Adam2 & $\mathrm{NE}$ & NE \\
\hline & 35 & -3.1 & Mmp9 & $\mathrm{I}$ & I & & & & & \\
\hline \multirow{4}{*}{$\begin{array}{l}\text { Cytokine, growth } \\
\text { factors and their } \\
\text { receptors }\end{array}$} & 39 & -6.0 & Fgfr1 & NE & I & & & & & \\
\hline & 40 & -5.5 & Pdgfrb & $\mathrm{I}$ & I & & & & & \\
\hline & 41 & -4.1 & Tgfbr1 & I & I & & & & & \\
\hline & 45 & -3.0 & Tgfb1 & $\mathrm{I}$ & $\mathrm{I}$ & & & & & \\
\hline \multirow[t]{3}{*}{ Structural molecule } & 47 & -7.1 & Vim & I & I & 46 & -9.9 & Add2 & I & $\mathrm{NE}$ \\
\hline & 49 & -3.3 & Acta2 & I & I & 48 & -4.2 & Tubb & $\mathrm{NE}$ & $\mathrm{NE}$ \\
\hline & 50 & -3.0 & Gfap & I & I & & & & & \\
\hline \multicolumn{11}{|l|}{ Up-regulation } \\
\hline \multirow{3}{*}{$\begin{array}{l}\text { Cytokine, growth } \\
\text { factors and their } \\
\text { receptors }\end{array}$} & 122 & 3.1 & Hgf & I & NE & 62 & 5.9 & $\mathrm{Il1}$ rl2 & $\mathrm{NE}$ & $\mathrm{NE}$ \\
\hline & & & & & & 121 & 3.3 & Il18 & $\mathrm{NE}$ & $\mathrm{NE}$ \\
\hline & & & & & & & & & & \\
\hline \multirow{6}{*}{$\begin{array}{l}\text { Structural molecule } \\
\text { Fatty acid } \\
\text { metabolism }\end{array}$} & 123 & 3.9 & Des & I & I & & & & & \\
\hline & & & & & & 102 & 3.4 & Acsl3 & $\mathrm{NE}$ & $\mathrm{NE}$ \\
\hline & & & & & & 120 & 3.4 & Ppara & $\mathrm{NE}$ & $\mathrm{NE}$ \\
\hline & & & & & & 104 & 3.3 & Acsl4 & $\mathrm{NE}$ & $\mathrm{NE}$ \\
\hline & & & & & & 112 & 3.1 & Slc27a2 & $\mathrm{NE}$ & $\mathrm{NE}$ \\
\hline & & & & & & 114 & 3.0 & Acsl6 & $\mathrm{NE}$ & $\mathrm{NE}$ \\
\hline
\end{tabular}

No., number (numbers are identical to those in Fig. 1); HSC, hepatic stellate cell; MFLC, myofibroblast-like cell; AF, activated fibroblast; I, increase; NE, not evaluated. Gene symbols: Acs13, long-chain-fatty-acid-CoA ligase 3; Acs14, long-chain-fatty-acid-CoA ligase 4; Acsl6, longchain-fatty-acid-CoA ligase 6; Acta2, aortic smooth muscle; Adam17, a disintegrin and metalloproteinase domain 17 (tumor necrosis factor $\alpha$, converting enzyme); Adam2, a disintegrin and metalloprotease domain 2; Add2, 3 adducin; Des, desmin; Ece1, endothelin-converting enzyme 1; Fgfr1, basic fibroblast growth factor receptor 1; Gfap, glial fibrillary acidic protein, astrocyte; Hapln2, hyaluronan and proteoglycan link protein 2; Has2, hyaluronan synthase 2; Hgf, hepatocyte growth factor; Hmmr, hyaluronan mediated motility receptor; Il18, interleukin-18; Il1rl2, interleukin-1 receptor-like 2; Ilf3, interleukin enhancer-binding factor 3; Mmp9, matrix metalloproteinase-9; Pdgfrb, $\beta$ platelet-derived growth factor receptor; Plat, tissue-type plasminogen activator; Ppara, peroxisome proliferator activated receptor $\alpha$; Slc27a2, very-long-chain acyl-CoA synthetase; Tgfb1, transforming growth factor $\beta 1$; Tgfbr1, TGF- $\beta$ receptor type I; Tubb, tubulin $ß$ chain; Vim, vimentin.

esters from chylomicron remnants, and after hydrolysis the retinol is transferred to HSCs and subsequently stored as esters of long-chain fatty acids. After administration of longchain fatty acids or retinol, retinol ester droplets are formed. Thus, an increase of cytoplasmic long-chain fatty acids may contribute to the formation of retinol-rich droplets in HSCs.

mRNA/protein expression of ADAM17 and TNF- $\alpha$ in HSCs after IFN- $\gamma$ treatment and concentration of TNF- $\alpha$ in culture supernatant. First, using quantitative PCR, we examined the expression of ADAM17 and TNF- $\alpha$ mRNAs after IFN- $\gamma$ treatment for $6 \mathrm{~h}$ (Table IV, Fig. 5). IFN- $\gamma$ treatment induced down-regulation of ADAM17 mRNA expression (Fig. 5A) but not that of TNF- $\alpha$ mRNA (Fig. 5B). Western blotting confirmed the decrease of ADAM17 protein expression after IFN- $\gamma$ treatment for $48 \mathrm{~h}$ (Fig. 3), but that of pro-TNF- $\alpha$ $(26 \mathrm{kDa})$ was not altered (the signals being relatively weak both before and after treatment). These results suggested that 
A

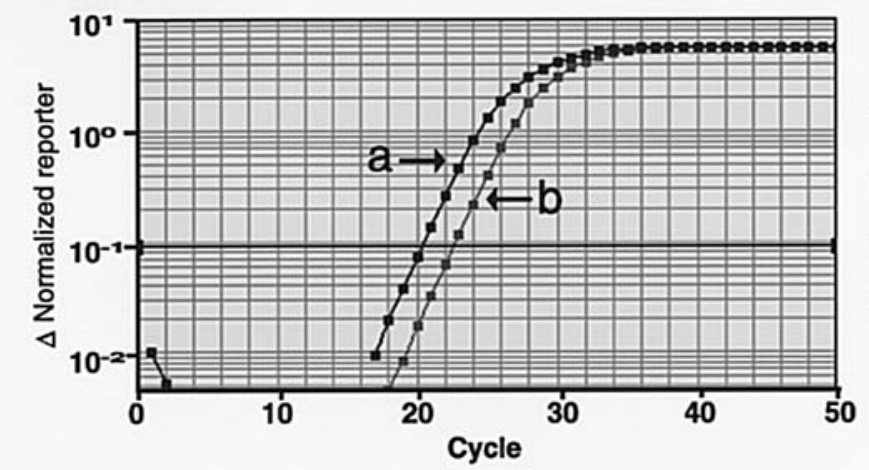

B

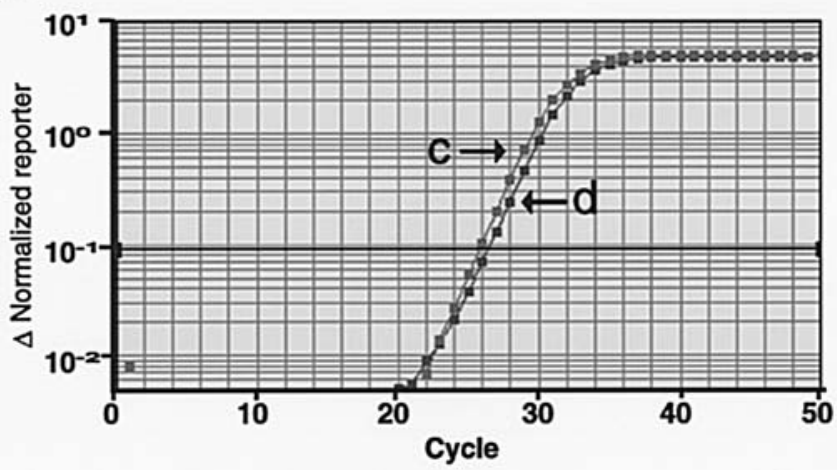

Figure 5. Amplification plots for ADAM17 (A) and TNF- $\alpha$ (B). mRNAs extracted from HSCs with (b and d) and without (a and c) IFN- $\gamma$ treatment. Decreased expression of ADAM17 mRNA (a and $b$ ) but not TNF- $\alpha$ mRNA (c and d) was observed after IFN- $\gamma$ treatment.

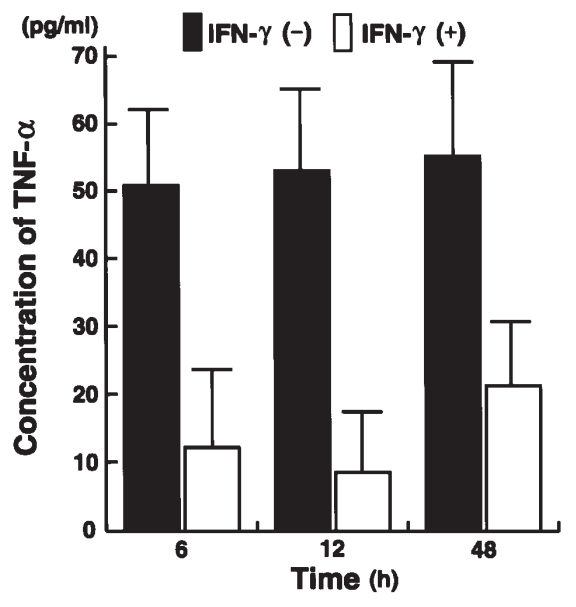

Figure 6. Concentrations of TNF- $\alpha$ in supernatant of HSC cultures with and without IFN- $\gamma$ treatment for 6,12 and $48 \mathrm{~h}$. A marked decrease of TNF- $\alpha$ was observed, irrespective of duration.

Table IV. Results of real-time quantitative PCR for TNF- $\alpha$ and ADAM17 expression after IFN- $\gamma$ treatment for $6 \mathrm{~h}$ using a comparative $\mathrm{Ct}$ method ( $\Delta \Delta \mathrm{Ct}$ ratio).

$\Delta \mathrm{Ct}$ ratio of targets

(with/without IFN- $\gamma$ treatment)

\begin{tabular}{lccc} 
Subjects & Mean & SD & CV (\%) \\
\hline TNF- $\alpha$ & 1.025 & 0.380 & 5.0 \\
ADAM17 & 0.586 & 0.270 & 4.3 \\
\hline
\end{tabular}

$\mathrm{SD}$, standard deviation; $\mathrm{CV}$, coefficient of variation.

IFN- $\gamma$ treatment affected the expression of ADAM17 but not that of TNF- $\alpha$. We next examined the concentration of TNF- $\alpha$ in the culture supernatant using a Suspension Array System. The concentration of TNF- $\alpha$ was almost constant for 6,12 , and $48 \mathrm{~h}$ in the non-treatment control, but markedly downregulated by IFN- $\gamma$ treatment for any duration (Fig. 6).

\section{Discussion}

Several cytokines regulating the inflammatory response to injury modulate hepatic fibrogenesis in vivo and in vitro (28). Among them, TNF- $\alpha$ plays a pivotal role in stimulating HSC activation regardless of the inflammatory etiology. It is well known that hepatocytes, Kupffer cells, sinusoidal endothelial cells and inflammatory cells secrete TNF- $\alpha$, while HSCs themselves have not been considered a TNF- $\alpha$-producing cell type (29). Our results of quantitative PCR and Western blot analysis suggested that INF- $\gamma$ treatment of cultured HSCs decreased TNF- $\alpha$ secretion through down-regulation of ADMA17 expression, rather than down-regulation of TNF- $\alpha$ expression itself. The autocrine action of TNF- $\alpha$ might partly contribute to the mechanism of activation of cultured HSCs, and downregulation of ADAM17 by IFN- $\gamma$ treatment might block its auto-activation mechanism.

IFN- $\gamma$ belongs to the type II interferon family, and selectively binds to the type II IFN receptor (consisting of two distinct subunits, IFNGR1 and IFNGR2) followed by activation of the JAK-STAT signaling pathway (30). Transcription of type II IFN-dependent genes is regulated by GAS (IFN- $\gamma$-activated site) elements, and STAT1 is the most important IFN- $\gamma$-activated factor for the regulation of these transcriptional responses (30). However, in a database search, we failed to find any GAS element in the promoter region of the rat ADAM17 gene. Therefore, repression of ADAM17 mRNA/protein expression may occur through an indirect response to IFN- $\gamma$-JAK-STAT signaling.

ADAM17 has been identified as the main secretase responsible for releasing the soluble form of TNF- $\alpha$ from the plasma membrane $(31,32)$. Recent studies have demonstrated that ADAM17 plays a pivotal role in development through the processing of numerous growth factors and their receptors, such as TGF- $\alpha$ (33), heparin-binding epidermal growth factorlike growth factor (HB-EGF) (34), amphiregulin (34), neuregulins (35), TrkA (36), growth hormone receptors (37), and others. A recent in vitro study showed that ADAM17dependent shedding of TGF- $\alpha$ and HB-EGF was stimulated by angiotensin II (AngII), and transactivated EGFR (38). Lautrette et al (39) demonstrated that model mice with chronic renal disease induced by AngII infusion could be rescued by 
transfection of dominant negative form of epidermal growth factor receptor (EGFR) as well as by administration of ADAM17 inhibitor. These reports suggest that ADAM17 inhibitors may prevent cell proliferation and matrix deposition by evading the AngII-EGFR pathway, and are suitable as therapeutic agents for chronic renal and cardiovascular diseases characterized by marked fibrosis $(38,39)$.

AngII also seems to play a pivotal role in liver fibrosis. Activated HSCs produce AngII in vitro and in vivo $(40,41)$. AngII induces hepatic inflammation and stimulates an array of fibrogenic actions in activated HSCs, including cell proliferation, cell migration, secretion of proinflammatory cytokines, and collagen synthesis (42-44). Moreover, pharmacologic and/ or genetic ablation of the renin-angiotensin system markedly attenuates experimental liver fibrosis (45-51). The same mechanism (AngII-ADAM17-TGF- $\alpha /$ HB-EGF-EGFR) may exist in activated HSCs, and IFN- $\gamma$ represses the pathway through down-regulation of ADAM17 expression.

ADAM17 also cleaves several cytokines and their receptors, such as soluble TNF- $\alpha, \mathrm{TNF}-\alpha$ receptors (33), interleukin (IL)-1-RII (52), and IL-6-R $\alpha$ (53). These factors contribute to accelerating the activation of HSCs. In fact, we have confirmed that the concentrations of IL- 1 and IL- 6 are decreased in the supernatant of cultured HSCs after IFN- $\gamma$ treatment (data not shown). IFN- $\gamma$ may induce changes in activated HSCs toward a quiescent phenotype through down-regulation of multiple cytokines and their receptors.

Our proteomic analysis indicated that several factors were associated with the HSC phenotypic transformation response to IFN- $\gamma$ treatment. Although the relationship of both the TGF- $\$ 1$ and PDGF signaling pathways to HSC activation has been well described, few studies have focused on the function of HSCs as fat-storing cells. We demonstrated up-regulation of enzymes involved in long-chain fatty acid synthesis, and this is an aspect that will warrant further examination. Quiescent HSCs express markers that are characteristic of adipocytes (e.g., PPARs), and the expression of these markers is increased in activated HSCs (54). A few reports have noted that IFN- $\gamma$ down-regulates PPAR $\gamma$ mRNA/protein expression through STAT signaling in adipocytes (55). Further studies will be required to clarify the mechanisms involved in the phenotypic change of activated HSCs to fat-storing cells.

In this study we have demonstrated that several pathways responding to IFN- $\gamma$ treatment appear to induce changes in activated HSCs toward a quiescent phenotype. A recent clinical trial of IFN- $\gamma$ administration has demonstrated an effective antifibrogenic action in patients with chronic hepatitis B virus infection (56). It is anticipated that combination therapy with IFN- $\gamma$ and other drugs (e.g., AngII antagonist or ADAM17 inhibitors) will be developed for the treatment and prevention of liver fibrosis.

\section{References}

1. Milani S, Herbst H, Schuppan D, Hahn EG and Stein H: In situ hybridization for procollagen types I, III and IV mRNA in normal and fibrotic rat liver: evidence for predominant expression in nonparenchymal liver cells. Hepatology 10: 84-92, 1989.

2. Friedman SL: Seminars in medicine of the Beth Israel Hospital, Boston. The cellular basis of hepatic fibrosis. Mechanisms and treatment strategies. N Engl J Med 328: 1828-1835, 1993.
3. Yokoi Y, Namihisa T, Kuroda H, et al: Immunocytochemical detection of desmin in fat-storing cells (Ito cells). Hepatology 4 : 709-714, 1984.

4. Pinzani M, Gesualdo L, Sabbah GM and Abboud HE: Effects of platelet-derived growth factor and other polypeptide mitogens on DNA synthesis and growth of cultured rat liver fat-storing cells. J Clin Invest 84: 1786-1793, 1989.

5. Ramadori G, Veit T, Schwogler S, et al: Expression of the gene of the alpha-smooth muscle-actin isoform in rat liver and in rat fat-storing (ITO) cells. Virchows Arch B Cell Pathol Incl Mol Pathol 59: 349-357, 1990.

6. Hendriks HF, Verhoofstad WA, Brouwer A, De Leeuw AM and Knook DL: Perisinusoidal fat-storing cells are the main vitamin A storage sites in rat liver. Exp Cell Res 160: 138-149, 1985

7. Blomhoff R and Wake K: Perisinusoidal stellate cells of the liver: important roles in retinol metabolism and fibrosis. FASEB J 5: 271-277, 1991.

8. Friedman SL, Rockey DC, McGuire RF, Maher JJ, Boyles JK and Yamasaki G: Isolated hepatic lipocytes and Kupffer cells from normal human liver: morphological and functional characteristics in primary culture. Hepatology 15: 234-243, 1992.

9. Rockey DC, Boyles JK, Gabbiani G and Friedman SL: Rat hepatic lipocytes express smooth muscle actin upon activation in vivo and in culture. J Submicrosc Cytol Pathol 24: 193-203, 1992.

10. Burt AD, Le Bail B, Balabaud C and Bioulac-Sage P: Morphologic investigation of sinusoidal cells. Semin Liver Dis 13: 21-38, 1993.

11. Seyer JM, Hutcheson ET and Kang AH: Collagen polymorphism in normal and cirrhotic human liver. J Clin Invest 59: 241-248, 1977.

12. Kent G, Gay S, Inouye T, Bahu R, Minick OT and Popper H: Vitamin A-containing lipocytes and formation of type III collagen in liver injury. Proc Natl Acad Sci USA 73: 3719-3722, 1976 .

13. Scharffetter K, Heckmann M, Hatamochi A, et al: Synergistic effect of tumor necrosis factor-alpha and interferon-gamma on collagen synthesis of human skin fibroblasts in vitro. Exp Cell Res 181: 409-419, 1989.

14. Jimenez SA, Freundlich B and Rosenbloom J: Selective inhibition of human diploid fibroblast collagen synthesis by interferons. J Clin Invest 74: 1112-1116, 1984.

15. Rosenbloom J, Feldman G, Freundlich B and Jimenez SA: Transcriptional control of human diploid fibroblast collagen synthesis by gamma-interferon. Biochem Biophys Res Commun 123: 365-372, 1984

16. Duncan MR and Berman B: Gamma interferon is the lymphokine and beta interferon the monokine responsible for inhibition of fibroblast collagen production and late but not early fibroblast proliferation. J Exp Med 162: 516-527, 1985.

17. Goldring MB, Sandell LJ, Stephenson ML and Krane SM: Immune interferon suppresses levels of procollagen mRNA and type II collagen synthesis in cultured human articular and costal chondrocytes. J Biol Chem 261: 9049-9055, 1986.

18. Smith DD, Gowen M and Mundy GR: Effects of interferongamma and other cytokines on collagen synthesis in fetal rat bone cultures. Endocrinology 120: 2494-2499, 1987.

19. Tsuruoka N, Sugiyama M, Tawaragi Y, et al: Inhibition of in vitro angiogenesis by lymphotoxin and interferon-gamma. Biochem Biophys Res Commun 155: 429-435, 1988.

20. Granstein RD, Deak MR, Jacques SL, et al: The systemic administration of gamma interferon inhibits collagen synthesis and acute inflammation in a murine skin wounding model. J Invest Dermatol 93: 18-27, 1989.

21. Shen H, Zhang M, Minuk GY and Gong Y: Different effects of rat interferon alpha, beta and gamma on rat hepatic stellate cell proliferation and activation. BMC Cell Biol 3: 9, 2002.

22. Vaillant B, Chiaramonte MG, Cheever AW, Soloway PD and Wynn TA: Regulation of hepatic fibrosis and extracellular matrix genes by the th response: new insight into the role of tissue inhibitors of matrix metalloproteinases. J Immunol 167: 7017-7026, 2001.

23. Senoo H: Structure and function of hepatic stellate cells. Med Electron Microsc 37: 3-15, 2004.

24. Rockey DC, Maher JJ, Jarnagin WR, Gabbiani G and Friedman SL: Inhibition of rat hepatic lipocyte activation in culture by interferon-gamma. Hepatology 16: 776-784, 1992.

25. Rosenfeld J, Capdevielle J, Guillemot JC and Ferrara P: In-gel digestion of proteins for internal sequence analysis after oneor two-dimensional gel electrophoresis. Anal Biochem 203: 173-179, 1992. 
26. Katayama H, Nagasu T and Oda Y: Improvement of in-gel digestion protocol for peptide mass fingerprinting by matrixassisted laser desorption/ionization time-of-flight mass spectrometry. Rapid Commun Mass Spectrom 15: 1416-1421, 2001.

27. Aarskog NK and Vedeler CA: Real-time quantitative polymerase chain reaction. A new method that detects both the peripheral myelin protein 22 duplication in Charcot-Marie-Tooth type 1A disease and the peripheral myelin protein 22 deletion in hereditary neuropathy with liability to pressure palsies. Hum Genet 107: 494-498, 2000.

28. Marra F: Chemokines in liver inflammation and fibrosis. Front Biosci 7: 1899-1914, 2002.

29. Bataller R and Brenner DA: Liver fibrosis. J Clin Invest 115 : 209-218, 2005.

30. Platanias LC: Mechanisms of type-I- and type-II-interferonmediated signalling. Nat Rev Immunol 5: 375-386, 2005.

31. Black RA, Rauch CT, Kozlosky CJ, et al: A metalloproteinase disintegrin that releases tumour-necrosis factor-alpha from cells. Nature 385: 729-733, 1997.

32. Moss ML, Jin SL, Milla ME, et al: Cloning of a disintegrin metalloproteinase that processes precursor tumour-necrosis factor-alpha. Nature 385: 733-736, 1997.

33. Peschon JJ, Slack JL, Reddy P, et al: An essential role for ectodomain shedding in mammalian development. Science 282: 1281-1284, 1998

34. Sunnarborg SW, Hinkle CL, Stevenson M, et al: Tumor necrosis factor-alpha converting enzyme (TACE) regulates epidermal growth factor receptor ligand availability. J Biol Chem 277: 12838-12845, 2002.

35. Montero JC, Yuste L, Diaz-Rodriguez E, Esparis-Ogando A and Pandiella A: Differential shedding of transmembrane neuregulin isoforms by the tumor necrosis factor-alpha-converting enzyme. Mol Cell Neurosci 16: 631-648, 2000.

36. Diaz-Rodriguez E, Montero JC, Esparis-Ogando A, Yuste L and Pandiella A: Extracellular signal-regulated kinase phosphorylates tumor necrosis factor alpha-converting enzyme at threonine 735: a potential role in regulated shedding. Mol Biol Cell 13: 2031-2044, 2002.

37. Zhang Y, Jiang J, Black RA, Baumann G and Frank SJ: Tumor necrosis factor-alpha converting enzyme (TACE) is a growth hormone binding protein (GHBP) sheddase: the metalloprotease TACE/ADAM-17 is critical for (PMA-induced) GH receptor proteolysis and GHBP generation. Endocrinology 141: 4342-4348, 2000.

38. Mifune M, Ohtsu H, Suzuki H, et al: G protein coupling and second messenger generation are indispensable for metalloprotease-dependent, heparin-binding epidermal growth factor shedding through angiotensin II type-1 receptor. J Biol Chem 280: 26592-26599, 2005.

39. Lautrette A, Li S, Alili R, et al: Angiotensin II and EGF receptor cross-talk in chronic kidney diseases: a new therapeutic approach. Nat Med 11: 867-874, 2005.

40. Paizis G, Cooper ME, Schembri JM, Tikellis C, Burrell LM and Angus PW: Up-regulation of components of the renin-angiotensin system in the bile duct-ligated rat liver. Gastroenterology 123: 1667-1676, 2002.
41. Bataller R, Sancho-Bru P, Gines P, et al: Activated human hepatic stellate cells express the renin-angiotensin system and synthesize angiotensin II. Gastroenterology 125: 117-125, 2003.

42. Bataller R, Schwabe RF, Choi YH, et al: NADPH oxidase signal transduces angiotensin II in hepatic stellate cells and is critical in hepatic fibrosis. J Clin Invest 112: 1383-1394, 2003.

43. Bataller R, Gines P, Nicolas JM, et al: Angiotensin II induces contraction and proliferation of human hepatic stellate cells. Gastroenterology 118: 1149-1156, 2000.

44. Bataller R, Gabele E, Schoonhoven R, et al: Prolonged infusion of angiotensin II into normal rats induces stellate cell activation and proinflammatory events in liver. Am J Physiol Gastrointest Liver Physiol 285: G642-G651, 2003.

45. Kanno K, Tazuma S and Chayama K: AT1A-deficient mice show less severe progression of liver fibrosis induced by $\mathrm{CCl}(4)$. Biochem Biophys Res Commun 308: 177-183, 2003.

46. Jonsson JR, Clouston AD, Ando Y, et al: Angiotensin-converting enzyme inhibition attenuates the progression of rat hepatic fibrosis. Gastroenterology 121: 148-155, 2001.

47. Paizis G, Gilbert RE, Cooper ME, et al: Effect of angiotensin II type 1 receptor blockade on experimental hepatic fibrogenesis. J Hepatol 35: 376-385, 2001.

48. Ramalho LN, Ramalho FS, Zucoloto S, et al: Effect of losartan, an angiotensin II antagonist, on secondary biliary cirrhosis. Hepatogastroenterology 49: 1499-1502, 2002.

49. Wei HS, Lu HM, Li DG, et al: The regulatory role of AT 1 receptor on activated HSCs in hepatic fibrogenesis: effects of RAS inhibitors on hepatic fibrosis induced by $\mathrm{CCl}(4)$. World $\mathrm{J}$ Gastroenterol 6: 824-828, 2000.

50. Wei HS, Li DG, Lu HM, et al: Effects of AT1 receptor antagonist, losartan, on rat hepatic fibrosis induced by $\mathrm{CCl}(4)$. World $\mathrm{J}$ Gastroenterol 6: 540-545, 2000.

51. Tuncer I, Ozbek H, Ugras S and Bayram I: Anti-fibrogenic effects of captopril and candesartan cilexetil on the hepatic fibrosis development in rat. The effect of AT1-R blocker on the hepatic fibrosis. Exp Toxicol Pathol 55: 159-166, 2003.

52. Reddy P, Slack JL, Davis R, et al: Functional analysis of the domain structure of tumor necrosis factor-alpha converting enzyme. J Biol Chem 275: 14608-14614, 2000.

53. Althoff K, Reddy P, Voltz N, Rose-John S and Mullberg J: Shedding of interleukin- 6 receptor and tumor necrosis factor alpha. Contribution of the stalk sequence to the cleavage pattern of transmembrane proteins. Eur J Biochem 267: 2624-2631, 2000 .

54. Hellemans K, Michalik L, Dittie A, et al: Peroxisome proliferatoractivated receptor-beta signaling contributes to enhanced proliferation of hepatic stellate cells. Gastroenterology 124: 184-201, 2003.

55. Waite KJ, Floyd ZE, Arbour-Reily P and Stephens JM: Interferongamma-induced regulation of peroxisome proliferator-activated receptor gamma and STATs in adipocytes. J Biol Chem 276: 7062-7068, 2001.

56. Weng HL, Wang BE, Jia JD, et al: Effect of interferon-gamma on hepatic fibrosis in chronic hepatitis B virus infection: a randomized controlled study. Clin Gastroenterol Hepatol 3: 819-828, 2005. 